\title{
KEEFEKTIFAN TEKNIK STORYBOARD DALAM PEMBELAJARAN KETERAMPILAN BERCERITA SISWA KELAS VII A MTS MUHAMMADYAH LIMBUNG
}

\author{
Kartini \\ Pendidikan Bahasa Indonesia, \\ kartinimustika83@gmail.com
}

\begin{abstract}
ABSTRAK
Penelitian ini bertujuan mendeskripsikan keefektifan teknik storyboard dalam pembelajaran keterampilan bercerita siswa kelas VII A MTs Muhammadiyah Limbung. Penelitian ini bersifat deskriptif kuantitatif. Desain penelitian yang digunakan dalam penelitian ini adalah desain pra experimental. Pencapaian hasil belajar pembelajaran bercerita siswa kelas VII A MTs Muhammadiyah Limbung setelah mengikuti pembelajaran dengan teknik storyboard memiliki skor rata-rata $(84,19)$ dimana dari 37 siswa dan semua siswa tuntas siswa dengan memenuhi Kriteria Ketuntasan Minimal (KKM) dengan skor tertinggi (90) dan skor terendah (75). Dari pencapaian ini, (99, 99\%) siswa mencapai Kriteria Ketuntasan Minimal (KKM). Dengan menggunakan uji Kolmogorov-Smirnov, hasil analisis skor rata-rata untuk pretest menunjukkan nilai $\mathrm{p}_{\text {value }}>\alpha$ yaitu $(0,56)$ $>0,05$ dan skor rata-rata untuk posttest menunjukkan nilai $\mathrm{p}_{\text {value }}>\alpha$ yaitu $(0,09)>0,05$. Hal ini menunjukkan bahwa skor pretest dan posttest termasuk kategori normal. Berdasarkan hasil analisis SPSS, tampak bahwa Nilai p (sig.(2-tailed)) adalah $0,000<0,05$ menunjukan bahwa rata-rata hasil belajar siswa setelah diajar menggunakan teknik storyboard lebih dari 74,9 Ini berarti bahwa $\mathrm{H}_{0}$ ditolak dan $\mathrm{H}_{1}$ diterima yakni rata-rata hasil belajar (posttest) siswa kelas VII A MTs Muhammadiyah Limbung. Berdasarkan hasil penelitian di atas dapat disimpulkan bahwa pembelajaran keterampilan bercerita menggunakan teknik storyboard lebih efektif dibandingkan dengan metode pembelajaran konvensional. Dari teknik pembelajaran tersebut anak-anak lebih terstimulasi daya pikir dan daya tangkapnya dalam menceritakan suatu kejadian atau pengelaman dengan menggunakan media visual sebagai penyampaiannya.
\end{abstract}

Kata kunci : Teknik storyboard, pra experimental, keterampilan bercerita.

\begin{abstract}
The objective of this research was to describe the effectiveness of storyboard in learning storytelling skill of second year students of class VII A at MTs Muhammadiyah Limbung. This research used descriptive quantitative method with the research design was pre-experimental design. The achievement of students result in learning storytelling had the average (84, 19) of 37 students and all of the student were completed the Kriteria Ketuntasan Minimal (KKM) with the higher score was (90) and the lower score was (75). Since the achievement, (99, 99\%) students achieved Kriteria Ketuntasan Minimal $(\mathrm{KKM})$. By using Kolmogorov-Smirnov test, the result of the average score analysis for pre-test shown that $\mathrm{P}_{\text {value }}>\alpha$ was $(0$, 56) $>0,05$ and the average score for post-test shown that $\mathrm{Pv}_{\text {alue }}>\alpha$ was $(0,09)>0,05$. The data shown that the result of pretest and post-test included in normal category. Based on the result of SPSS analysis, shown that P (sig. (2-tailed) was 0,000 $<0,05$. It shown that the average of students' result in learning after taught by using storyboard technique was more than 74, 9. It implied that $\mathrm{H}_{0}$ was rejected and $\mathrm{H}_{1}$ was accepted which implied that the average of students' result (post-test) of second year students of class VII A MTs Muhammadiyah Limbung. Based on the result of the research above, could be concluded that learning storytelling skill by using storyboard technique was more effective than the conventional method of learning. By using the technique, students' intellect and grasp skill were more stimulated in telling an event or their experience by using visual aid as the aid in conveying the event or experience.
\end{abstract}

Keywords: storyboard technique, pre-experimental, storytelling skill.

\section{PENDAHULUAN}

\section{A. Latar Belakang Masalah}

Bahasa Indonesia sebagai bahasa persatuan merupakan pelajaran wajib bagi setiap jenjang pendidikan di sekolah. Bahasa Indonesia memiliki 4 aspek keterampilan berbahasa, yakni (1) Menyimak, (2) Berbicara, (3) Membaca, dan (4) Menulis. Keempat keterampilan berbahasa di atas saling berkaitan satusama lain, sehingga untuk mempelajari salah satu keterampilan berbahasa, beberapa keterampilan berbahasa lainnya juga akan terlibat. Berbicara atau berkomunikasi dengan baik adalah dambaan setiap orang. Sebab, kemampuan berbicara atau berkomunikasi dengan orang lain secara baik dapat memberikan energi positif terhadap kehidupan kita. Menurut Burhan Nurgiyantoro (2001: 278), ada beberapa bentuk kegiatan berbicara yang dapat dilatihkan untuk mengembangkan keterampilan berbicara siswa. Bentuk-bentuk kegiatan tersebut yaitu: pembicaraan berdasarkan gambar, wawancara, pidato, bercerita, dan diskusi. Bercerita adalah menuturkan sesuatu yang mengisahkan tentang perbuatan atau sesuatu kejadian yang disampaikan secara lisan dengan tujuan membagikan pengalaman dan pengetahuan kepada orang lain (Bachtiar S Bachir: 2005:10). Dengan kata lain, bercerita adalah merunutkan sesuatu yang mengisahkan tentang perbuatan atau 
suatu kejadian secara lisan dalam upaya untuk mengembangkan potensi kemampuan berbahasa (Latief, H., \& Muhsin, M. A., 2015). Bercerita merupakan salah satu kebiasaan masyarakat sejak dahulu sampai sekarang.

Keterampilan bercerita yang baik memerlukan pengetahuan, pengalaman serta kemampuan berpikir yang memadai. Selain itu, dalam bercerita juga diperlukan penguasaan beberapa keterampilan, yaitu ketepatan tatabahasa sehingga hubungan antar kata dan kalimat menjadi jelas (Muhsin, A. (2016). Ketepatan kata dan kalimat sangat perlu dikuasai dalam bercerita, sebab dengan menggunakan kata dan kalimat yang tepat dalam bercerita akan memudahkan pendengar memahami isi cerita yang dikemukakan oleh pembicara. Isi cerita yang mudah dipahami akan menunjang dalam penyampaian maksud yang sama antara pembicara dan pendengar, sehingga tujuan penyampaian makna cerita juga dapat tercapai.

Maka dari itu, seorang guru harus bisa mengembangkan kemampuan berkomunikasi siswa baik secara lisan (berbicara) maupun secara tulisan dengan berbagai cara. Sebagaimana disebutkan oleh Supriyadi (2005: 179) bahwa sebagian besar siswa belum lancar berbicara dalam bahasa Indonesia. Siswa yang belum lancar berbicara tersebut dapat disertai dengan sikap siswa yang pasif, malas berbicara, sehingga siswa merasa takut salah dan malu, atau bahkan kurang berminat untuk berlatih berbicara di depan kelas. Fenomena anak-anak dewasa ini, yang lebih mementingkan gadget dibanding kenyataan yang ada membuat anak-anak menjadi anti sosial dan lebih mementingkan diri sendiri. Penulis ingin menciptakan suasana kelas yang kondusif dan terkendali dengan menerapkan teknik Storyboard (Sketsa gambar yang disusun hingga mudah untuk dipahami) sebagai salah satu metode pemecahan agar siswa lebih fokus dan tertarik dengan pelajaran Bahasa Indonesia khususnya dalam pembelajaran bercerita.

Storyboard secara harfiah berarti dasar cerita, sedangkan definisi Storyboard adalah sketsa gambar yang disusun berurutan sesuai dengan naskah, dengan Storyboard kita dapat menyampaikan ide cerita kita kepada orang lain dengan lebih mudah, karena kita dapat menggiring khayalan seseorang mengikuti gambar-gambar yang tersaji, sehingga menghasilkan persepsi yang sama pada ide cerita kita.

Pada dasarnya, tujuan utama dari bercerita adalah untuk berkomunikasi atau bertukar informasi dengan orang lain. Agar dapat menyampaikan pikiran secara efektif, seorang yang bercerita harus memahami makna segala sesuatu yang ingin dikomunikasikan. Hal ini sejalan dengan pendapat Burhan Nurgiyantoro (2001: 277), yang mengemukakan bahwa tujuan bercerita adalah untuk mengemukakan sesuatu kepada orang lain. Sementara itu, Tarigan (1981: 17) mengungkapkan tiga tujuan umum dari kegiatan bercerita yaitu sebagai berikut:

a. Memberitahukan dan melaporkan (to inform),

b. Menjamu dan menghibur (to entertain),

c. Membujuk, mengajak, mendesak, dan meyakinkan (to persuade).

Dalam pembelajaran berceritapun seseorang berarti belajar untuk berkomunikasi. Pembelajaran bercerita dapat berlangsung jika setidak-tidaknya ada dua orang yang berinteraksi, atau seorang yang bercerita dan pendengar yang mendengarkan cerita tersebut.

Storyboard dapat dibuat dengan 2 cara, yaitu

a. Penggambaran cerita dalam bentuk strip (potongan-potongan gambar) sesuai perkiraan tampilan yang diharapkan di layar (seperti komik), disertai penjelasan lengkap mengenai cerita.

b. Membuat Storyboard dengan simbol, (ditujukan bagi yang tidak bisa menggambar). Jadi bentuk Storyboard bisa dibuat dengan simbol-simbol yang bisa dimengerti oleh orang lain. Contoh: penggambaran manusia dibuat dengan bentuk garis dan kepala bulat, atau bentuk simbol bahwa gambar dimaksud adalah manusia. Storyboard model ini harus diberi penjelasan maksud simbol tersebut.

Storyboard mempermudah siswa dalam menjawab pertanyaan dari guru. Seorang pembuat Storyboard harus mampu menceritakan sebuah cerita yang bagus. Untuk mencapainya, mereka harus mengetahui berbagai film, dengan pengertian tampilan yang bagus, komposisi, gambaran berurut dan editing. Mereka harus mampu untuk bekerja secara sendiri atau dalam sebuah bagian team. Mereka harus mampu menerima arahan dan juga bersiap membuat perubahan terhadap hasil kerja mereka.

\section{B. Rumusan Tujuan}


Berdasarkan pada uraian latar belakang yang telah dikemukakan di atas, maka rumusan masalah pada penelitian ini adalah bagaimana keefektifan teknik Storyboard dalam pembelajaran keterampilan bercerita siswa kelas VII A MTs Muhammadiyah Limbung?. Adapun tujuan penelitian adalah untuk mengetahui keefektifan teknik Storyboard dalam pembelajaran keterampilan bercerita siswa kelas VII A MTs Muhammadiyah Limbung.

\section{Jenis penelitian}

Penelitian yang dimaksudkan pada penelitian ini yakni hanya melibatkan satu kelas sebagai kelas eksperimen atau percobaan (Pra Experimental) yang dibagi menjadi dua kelompok. Tujuannya untuk mengetahui keefektifan teknik Storyboard dalam pembelajaran keterampilan bercerita siswa kelas VII A MTs Muhammadiyah Limbung.

\section{Variabel Penelitian dan Desain Penelitian}

\section{Variabel Penelitian}

Variabel ini melibatkan dua variabel, yaitu penggunaan teknik atau media dalam pembelajaran keterampilan bercerita siswa sebagai variabel bebas dan kemampuan bercerita siswa sebagai variabel terikat.

a. Variabel Bebas

Variabel bebas dalam penelitian ini adalah penggunaan teknik Storyboard dalam pembelajaran keterampilan bercerita $(\mathrm{X})$.

b. Variabel Terikat

Variabel terikat dalam penelitian ini adalah kemampuan siswa dalam berbicara khususnya 2. Desain Penelitian

keterampilan bercerita Kelas VII A MTs Muhammadiyah Limbung.

Untuk memperoleh data yang akurat sesuai dengan masalah penelitian ini dirancang melalui penelitian eksperimen. Jadi, desain penelitian yang digunakan dalam penelitian ini adalah desain pra experimental. Menurut Best, John W. (Sartika, 2012:34) bahwa penelitian eksperimental menyediakan metode sistematis dan logis untuk menjawab pertanyaan. Peneliti dapat memanipulasi kondisi tertentu agar subjek dapat dipengaruhi atau dapat diubah dengan memanipulasi sengaja dan sistematis.

\section{E. Populasi dan Sampel}

A. Populasi

Populasi adalah keseluruhan objek penelitian. Apabila seseorang ingin meneliti semua elemen yang ada di wilayah penelitian mana penelitian dinamakan sensus.

Berdasarkan keterangan di atas, maka dapat disimpulkan bahwa populasi adalah keseluruhan objek yang akan diteliti, kemudian populasi itu dibatasi sejumlah siswa atau individu yang paling sedikit mempunyai sifat yang sama. Oleh Karena itu, populasi adalah alat ukur dasar seorang peneliti dalam menentukan jenis, jumlah, dan kriteria sampel. Populasi dalam penelitian ini adalah seluruh siswa kelas VII MTs Muhammadiyah Limbung.

Tabel Jumlah Populasi Siswa Kelas VII MTs Muhammadiyah Limbung

\begin{tabular}{|l|l|l|}
\hline No & Kelas & Jumlah Siswa \\
\hline 1 & VII A & 37 Siswa \\
\hline 2 & VII B & 37 Siswa \\
\hline & Jumlah & 74 siswa \\
\hline
\end{tabular}

\section{B. Sampel}

Pengambilan sampel dalam penelitian ini menggunakan sampel acak (random sampling), karena siswa kelas VII memiliki peluang yang sama untuk dijadikan sampel. Berdasarkan hasil undian yang ditetapkan menjadi sampel adalah siswa kelas VII A sebanyak 37 orang siswa sebagai kelas eksperimen.

Tabel Jumlah Sampel Siswa Kelas VII A MTs Muhammadiyah Limbung 1

Perincian siswa kelas VII A 


\begin{tabular}{|l|l|}
\hline Siswa laki-laki & 17 orang \\
\hline Siswa perempuan & 20 orang \\
\hline Jumlah & $\mathbf{3 7}$ orang \\
\hline
\end{tabular}

\section{F. Definisi Operasional Variabel}

Untuk memperoleh gambaran yang jelas tentang variabel yang diselidiki maka perlu diberikan batasan pengertian variabel. Definisi operasional variabel dimaksudkan untuk menghindari salah penafsiran variabel. Oleh karena itu, variabel penelitian didefinisikan sebagai berikut:

a. Variabel bebas

Variabel bebas dalam penelitian ini adalah hasil belajar siswa. Hasil belajar siswa yang dipengaruhi dengan diterapkannya teknik Storyboard dalam pembelajaran bercerita.

b. Variabel terikat

Variabel terikat dalam penelitian ini adalah pengaruh teknik Storyboard dalam pembelajaran bercerita. Teknik Storyboard diharapkan mampu membawa pengaruh dalam hal peningkatan keterampilan bercerita siswa kelas VII MTs Muhammadiyah Limbung.

\section{G. Prosedur Penelitian}

Prosedur penelitian yang digunakan dalam penelitian ini adalah sebagai berikut:

1. Tahap sebelum eksperimen

Pada tahap ini dilakukan pretest, Yaitu suatu bentuk pertanyaan, yang dilontarkan guru kepada muridnya sebelum memulai suatu pelajaran. Pertanyaan yang ditanya adalah materi yang akan diajarkan pada hari itu (materi baru). Pertanyaan itu biasanya dilakukan guru di awal pembukaan pelajaran. Pretest diberikan dengan maksud untuk mengetahui apakah ada diantara murid yang sudah mengetahui mengenai materi yang akan diajarkan.

2. Tahap eksperimen

Tahap selanjutnya diadakan perlakuan (treatment) untuk mengetahui peningkatan kemampuan bercerita pada siswa dengan menggunaan teknik Storyboard pada kelas eksperimen.

3. Tahap Sesudah Eksperimen

Sebagai langkah terakhir setelah mendapat perlakuan pada kedua kelompok diberikan posttest dengan materi yang sama seperti pada waktu pretest. Pemberian posttest ini dimaksudkan untuk melihat pencapaian peningkatan kemampun bercerita pada siswa saat pretest dan posttest, apakah hasil siswa semakian meningkat, sama, atau mengalami penurunan.

H. Instrumen Penelitian

Adapun instrumen penelitian yang digunakan adalah sebagai berikut:

1. Tes hasil belajar

Dengan adanya tes hasil belajar kita dapat memperoleh informasi tentang kemampuan awal siswa sebelum diberikan perlakuan (pretest) serta tingkat pemahaman siswa terhadap materi yang telah diajarkan melalui teknik storyboard.

2. Lembar observasi aktivitas siswa

Instrumen ini digunakan untuk memperoleh informasi tentang aktivitas siswa dalam kelas selama pembelajaran keterampilan bercerita dengan teknik storyboard.

3. Lembar observasi keterlaksanaan proses pembelajaran

Lembar observasi keterlaksanaan metode pembelajaran bertujuan untuk mengetahui seberapa baik keterlaksanaan metode pada saat pembelajaran berlangsung. Butir-butir instrumen ini mengacu pada langkah-langkah metode pembelajaran yang disesuaikan dengan RPP. Pengamatan dilakukan sejak kegiatan pendahuluan hingga kegiatan penutup dan dibantu oleh seorang guru sebagai observer. Pengkategorian skor keterlaksanaan metode pembelajaran terdiri dari 4 kategori yakni (a) tidak terlaksana dengan baik, (b) kurang terlaksana, (c) terlaksana, (d) terlaksana dengan baik.

\section{Teknik Pengumpulan Data}

Adapun langkah-langkah pengumpulan data yang dilakukan adalah sebagai berikut:

1. Data hasil belajar siswa dikumpulkan melalui pemberian tes, yakni pretest diberikan sebelum treatment dengan penggunaan metode konvensional dan posttest diberikan setelah treatment berupa media projected visual. 
2. Data observasi aktivitas siswa (Pengamatan) dikumpulkan melalui lembar observasi yang diberikan kepada seorang observer untuk diisi dengan cara menuliskan cek list $(\sqrt{ })$ sesuai dengan keadaan yang diamati.

3. Data keterlaksanaan metode pembelajaran dikumpulkan dengan menggunakan lembar observasi keterlaksanaan metode pembelajaran. Data keterlaksanaan metode pembelajaran diperoleh dengan melakukan pengamatan terhadap aktivitas pembelajaran yang mengacu pada langkah-langkah metode pembelajaran yang disesuaikan RPP selama kegiatan pembelajaran berlangsung. Untuk mengukur, observer mengisi lembar keterlaksanaan metode pembelajaran dengan memberi tanda $(\sqrt{ })$ sesuai dengan keadaan yang diamati. Observasi dilakukan pada saat proses pembelajaran sedang berlangsung mulai dari kegiatan pendahuluan, kegiatan inti, dan kegiatan penutup.

J. Teknik Analisis Data

1. Analisis data hasil belajar siswa

Analisis data hasil belajar siswa dilakukan terhadap skor yang diperoleh siswa dari tes hasil belajar siswa setelah materi tuntas dibahas. Kriteria Ketuntasan Minimal (KKM) yang harus dipenuhi siswa adalah 75. Apabila siswa memperoleh skor $\geq 75$ maka siswa yang bersangkutan mencapai ketuntasan individu. Jika $\geq 80 \%$ dari mereka mencapai skor $\geq 75$ maka siswa yang bersangkutan mencapai ketuntasan secara klasikal.

a. Aspek Penilaian

Tabel Aspek Penilaian

\begin{tabular}{|c|l|c|}
\hline No & \multicolumn{1}{|c|}{ Aspek yang dinilai } & Skor \\
\hline 1 & Ketepatan ucapan & 20 \\
\hline 2 & Kenyaringan suara & 10 \\
\hline 3 & Gerak gerik dan mimik yang tepat & 20 \\
\hline 4 & Penguasan topik & 20 \\
\hline 5 & Pilihan kata $\quad$ Jumlah & 30 \\
\hline \multicolumn{2}{|c|}{} & 100 \\
\hline
\end{tabular}

Kriteria yang digunakan untuk menentukan kategori hasil belajar Bahasa Indonesia

berdasarkan nilai Kriteria Ketuntasan Minimal (KKM) adalah dinyatakan dalam tabel berikut:

\begin{tabular}{|c|c|}
\hline Skor & Kategori \\
\hline $0-59$ & Sangat Rendah \\
\hline $60-69$ & Rendah \\
\hline $70-79$ & Sedang \\
\hline $80-89$ & Tinggi \\
\hline $90-100$ & Sangat Tinggi \\
\hline
\end{tabular}

Tabel Kategorisasi Standar Ketuntasan Hasil Belajar Bahasa Indonesia Siswa Kelas VII A MTs Muhammadiyah Limbung

\begin{tabular}{|c|c|}
\hline Nilai & Kriteria \\
\hline$\geq 75$ & Tuntas \\
\hline$\leq 75$ & Tidak Tuntas \\
\hline
\end{tabular}

Sumber: (MTs Muhammadiyah Limbung, Kabupaten Gowa)

Berdasarkan tabel diatas bahwa siswa yang memperoleh nilai $\geq 75$ maka dapat dinyatakan tuntas belajar dalam proses belajar mengajar, dan siswa yang memperoleh nilai $<75$ maka siswa dinyatakan tidak tuntas dalam proses belajar mengajar. Sedangkan ketuntasan klasikal tercapai apabila $\geq 80 \%$ siswa di kelas tersebut telah dinyatakan tuntas dalam pembelajaran. Walaupun tidak mencapai

Kriteria ketuntasan hasil belajar tetapi terjadi peningkatan dari pretest ke posttest berarti lebih efektif setelah diterapkan model Pembelajaran Berbasis Masalah.

$$
\text { Ketuntasan belajar klasikal }=\frac{\text { banyaknya siswa dengan skor } \geq 75}{\text { banyaknya siswa }} \times 100 \%
$$


b. Analisis data aktivitas siswa

Adapun langkah-langkah untuk menentukan persentase rata-rata aktivitas siswa adalah sebagai berikut:

1) Menentukan banyaknya siswa yang aktif dalam proses pembelajaran.

2) Mencari persentase aktivitas siswa, dengan menggunakan rumus:

Keterangan:

$$
S=\frac{X}{N} \times 100 \%
$$

$S:$ Persentas

$X$ : Banyaknya siswa yang aktif

$N$ : Jumlah seluruh siswa pada kelas yang diberikan treatment

Kriteria aktivitas siswa dalam pembelajaran dikatakan aktif apabila jumlah siswa yang aktif telah mencapai $\geq 75 \%$.

c. Keterlaksanaan Proses Pembelajaran

Teknik analisis data terhadap keterlaksanaan proses pembelajaran digunakan analisis rata-rata. Artinya keterlaksanaan proses pembelajaran dihitung dengan cara menjumlah nilai tiap aspek kemudian membaginya dengan banyak aspek yang dinilai. Adapun pengkategorian keterlaksanaan model pembelajaran digunakan kategori pada tabel berikut:

Tabel Kategori Aspek Keterlaksanaan Proses Pembelajaran

\begin{tabular}{|l|c|c|}
\hline No & Skor Rata-rata & Kategori \\
\hline 1 & $1,00 \leq \overline{\boldsymbol{x}} \leq 1,40$ & Kurang Baik \\
\hline 2 & $1,50<\overline{\boldsymbol{x}} \leq 2,40$ & Cukup Baik \\
\hline 3 & $2,50<\overline{\boldsymbol{x}} \leq 3,40$ & Baik \\
\hline 4 & $3,50<\overline{\boldsymbol{x}} \leq 4,00$ & Sangat Baik \\
\hline
\end{tabular}

Keterangan:

$\overline{\boldsymbol{x}}=$ rata-rata skor keterlaksanaan pembelajaran.

2. Analisis Statistik Inferensial

Analisis statistik inferensial dimaksudkan untuk menguji hipotesis penelitian. Analisis statistik inferensial bertujuan untuk melakukan generalisasi yang meliputi estimasi (perkiraan) dan pengujian hipotesis berdasarkan suatu data. Sebelum melakukan pengujian hipotesis penelitian, terlebih dahulu dilakukan uji normalitas sebagai uji prasyarat.

a. Uji Normalitas

Uji normalitas merupakan langkah awal dalam menganalisis data secara spesifik. Uji normalitas digunakan untuk mengetahui data berdistribusi normal atau tidak. Untuk pengujian tersebut digunakan uji Anderson Darly atau Kolmogorow Smirnov dengan menggunakan taraf signifikansi $5 \%$ atau 0,05 , dengan syarat:

Jika $P_{\text {value }} \geq \alpha=0,05$ maka distribusinya adalah normal.

Jika $\mathrm{P}_{\text {value }}<\alpha=0,05$ maka distribusinya adalah tidak normal.

b. Pengujian Hipotesis Penelitian

Pengujian hipotesis berdasarkan Kriteria Ketuntasan Minimal (KKM) menggunakan uji kesamaan rata-rata yaitu dengan menerapkan teknik uji t satu sampel (One sample t-test).

Uji hipotesis dibuat dalam situasi ini, yaitu:

$$
\begin{aligned}
& \mathbf{H}_{\mathbf{0}}: \boldsymbol{\mu} \leq \mathbf{7 4 , 9} \text { melawan } \quad \mathbf{H}_{\mathbf{1}}: \boldsymbol{\mu}>\mathbf{7 4 , 9} \\
& \text { Keterangan: } \\
& \mu \text { : Parameter skor rata-rata hasil belajar siswa }
\end{aligned}
$$

Kriteria pengambilan keputusan adalah:

$\mathrm{H}_{\mathrm{o}}$ ditolak jika $P_{\text {-Value }}>\alpha$ dan $\mathrm{H}_{1}$ diterima jika $P_{\text {-Value }} \leq \alpha$, dimana $\alpha=5 \%$. Jika $P_{\text {-Value }}<\alpha$ berarti hasil belajar matematika siswa bisa mencapai KKM 75 .

K. HASIL PENELITIAN

\section{Pembahasan Hasil Analisis Deskriptif}


Pembahasan hasil analisis deskriptif tentang (1) ketuntasan belajar siswa serta peningkatannya, (2) aktivitas siswa dalam pembelajaran keterampilan bercerita, (3) Keterlaksanaan Proses Pembelajaran. Ketiga aspek tersebut akan diuraikan sebagai berikut:

a. Hasil Belajar Siswa

1) Hasil Belajar Siswa Sebelum Diterapkan Teknik Storyboard (Metode Konvensional)

Hasil analisis data hasil belajar siswa sebelum diterapkan teknik storyboard dalam pembelajaran bercerita menunjukkan bahwa dari 37 siswa keseluruhan hanya 8 siswa yang mencapai ketuntasan individu (mendapat skor prestasi minimal 75) dan 29 siswa yang tidak mencapai ketuntasan.

Hal ini membuktikan bahwa lebih banyak siswa yang mendapat nilai di bawah kriteria ketuntasan maksimal (KKM) yang telah ditetapkan, dengan kata lain hasil belajar siswa sebelum diterapkan teknik storyboard umumnya masih tergolong sangat rendah.

2) Hasil belajar siswa setelah diterapkan Teknik Storyboard

Hasil analisis data hasil belajar siswa setelah diterapkan teknik storyboard dalam pembelajaran menulis naskah drama menunjukkan semua siswa tuntas tapi ada beberapa orang yang mendapat nilai ambang KKM. Siswa mencapai ketuntasan minimal (mendapat skor minimal 75) dengan rata-rata 84,19\% sebanyak 37 orang.

Dengan kata lain hasil belajar siswa setelah diterapkan teknik storyboard mengalami peningkatan karena sudah memenuhi kriteria ketuntasan maksimal. Hal ini berarti bahwa teknik storyboard dapat membantu siswa untuk mencapai ketuntasan dalam pembelajaran keterampilan bercerita.

b. Aktivitas Siswa dalam Proses Pembelajaran Keterampilan Bercerita Siswa

Hasil pengamatan aktivitas siswa dalam pembelajaran keterampilan bercerita siswa melalui penerapan teknik storyboard pada siswa kelas VII A MTs Muhammadiyah Limbung dalam hasil pengamatan aktivitas siswa terlihat bahwa guru dan peserta didik aktif, di mana diperoleh bahwa rata-rata persentase aktivitas siswa dari pertemuan pertama sampai pertemuan keempat telah memenuhi kriteria waktu ideal. Hal ini menunjukkan bahwa secara umum dari pertemuan pertama sampai pertemuan keempat siswa yang diobservasi telah

\section{Keterlaksanaan Proses Pembelajaran}

melaksanakan aktivitas dalam penerapan teknik storyboard sesuai yang diharapkan.

Dari hasil pengamatan penelitian yang telah dilakukan, dapat diketahui bahwa dalam mengelola pembelajaran melalui teknik storyboard guru sudah melaksanakan pembelajaran dengan baik. Hal itu terlihat dari nilai rata-rata dari keseluruhan aspek yang diamati yaitu sebesar $(3,80)$ dan umumnya berada pada kategori (sangat baik).

\section{Pembahasan Hasil Analisis Inferensial}

Hasil analisis inferensial yang dimaksudkan adalah pembahasan terhadap hasil pengujian hipotesis yang telah dirumuskan sebelumnya. Hasil analisis inferensial menunjukkan bahwa data pretest dan posttest telah memenuhi uji normalitas yang merupakan uji prasyarat sebelum melakukan uji hipotesis. Data pretest dan posttest telah terdistribusi dengan normal karena nilai $\mathrm{P}>\alpha=0,05$. Karena data berdistribusi normal maka memenuhi kriteria untuk digunakannya uji-t untuk menguji hipotesis penelitian. Pengujian hipotesis pada penelitian ini menggunakan uji-t one sample test.

Hasil uji hipotesis dengan menggunakan uji-t one sample test pada data pretest dan data posttest. telah diperoleh nilai $\mathrm{p}$ (sig.(2-tailed)) adalah $0,000<0,05=\alpha$, sehingga $\mathrm{H}_{0}$ ditolak dan $\mathrm{H}_{1}$ diterima.

Dari hasil analisis deskriptif dan inferensial yang diperoleh, ternyata cukup mendukung teori yang telah dikemukakan pada kajian teori. Dengan demikian dapat disimpulkan bahwa "Teknik Storyboard efektif diterapkan dalam pembelajaran menulis naskah drama pada siswa kelas VII A MTs Muhammadiyah Limbung".

\section{DAFTAR PUSTAKA}

Arsyad, Azhar. 2013. Media Pembelajaran. Jakarta: PT Raja Grafindo Persada. 
Astianingsih. 2014. Penerapan Pendekatan Komunikatif dalam Proses Pembelajaran Keterampilan Berbicara untuk Meningkatkan Kemampuan Keterampilan Berbicara Siswa Kelas VII A MTs Muhammadiyah Panaikang Kabupaten Bantaeng. FKIP Universitas Muhammadiyah Makassar.

Bachir, S Bachtiar. 2005. Pengembangan Kegiatan Bercerita, Teknik dan Prosedurnya. Jakarta: Depdikbud.

Belawati, Tian, dkk. 2005. Application Of Educational Media At Universitas Terbuka, Indonesia. Educational Media in Asia.

Latief, H., \& Muhsin, M. A. (2015). Improving the students'speaking skill by using task-based approach at the second year students of sma negeri 2 sungguminasa kab. Gowa. JKIP (Jurnal Keguruan dan Ilmu Pendidikan), 2(2), 198-210.

. Improving the students'speaking skill by using task-based approach at the second year students of sma negeri 2 sungguminasa kab. gowa. jkip (Jurnal Keguruan dan Ilmu Pendidikan), 2(2), 198210.

Nurgiyantoro, Burhan. 2001. Penilaian dan Pengajaran Bahasa dan Sastra. Yogyakarta: BPEE Yogyakarta.

Muhsin, A. (2016). The Effectiveness of Positive Feedback in Teaching Speaking Skill. Lingua Cultura, 10(1), 25-30.

Nurgiyantoro, Burhan. 2010. Penilaian Pembelajaran Sastra Berbasis Kompetensi. Yogyakarta: BPFE.

Purwanto. 2004. Pengembangan Multimedia Pembelajaran. Makalah. Disampaikan dalam Lokakarya Pembelajaran Matematika. FMIPA UNY.

Supriyadi. 2005. Bahasa Indonesia 1. Jakarta: Depdikbud Dirjen Dikdasmen.

Tarigan, Djago dan Tarigan, Guntur Hendri. 1981. Teknik Pengajaran Keterampilan Berbahasa. Bandung: Angkasa.

Tim Penyusun FKIP Unismuh Makassar. Pedoman Penulisan Skripsi. Unismuh: Makassar. 